\title{
SALURAN MEDIA POLITIK DINASTI YASIN DALAM PILKADA KABUPATEN BOGOR
}

\author{
POLITICAL MEDIA CHANNEL YASIN DINASTY IN BOGOR REGENCY \\ ELECTION
}

Hudi Santoso ${ }^{1}$

\begin{abstract}
ABSTRAK
Metode yang digunakan dalam penulisan makalah ini menggunakan studi literatur (literature study) dan studi kasus (case study) terkait dengan saluran media komunikasi yang digunakan tim sukses Ade yasin dalam pilkada Kabupaten Bogor. Pada sebagian masyarakat akar rumput tim relawan Ade Yasin memandang pentingnya pembangunan media massa modern sebagai suatu kekuatan untuk mempengaruhi khalayak, sekaligus sebagai daya energi untuk mengerakkan modernisasi saluran media diantaranya penggunaan kekuatan media sosial. Dengan tujuan menanggulangi masalah-masalah yang dihadapi dalam hal hoax, termasuk hoax yang dikonotasikan membangun, bahasa, perbedaan tingkat pengetahuan, kepercayaan, dan kebiasaan, maka perluasan komunikasi berfungsi sebagai jembatan bagi sistem-sistem yang tadinya dicirikan oleh arus komunikasi yang heterogen.

Kata-kata Kunci: Saluran media, politik, Tim Ade Yasin,
\end{abstract}

\begin{abstract}
This research used literature study and case study regarding the related communication media channels of Ade Yasin's supportings Team at Bogor Regency Election. Volunteer team of Ade Yasin considered the importance of building modern mass media at grass root society as the power to influence them, thus as the energy to move the modernization of media channel, such as using social media. In orderto overcome the problems faced such as hoax, including"constructing hoax", language, knowlegde level's difference, beliefs and habits, broadening the communication has functioned as the bridge for systems which have the characteristics of heterogenous communication flow.
\end{abstract}

Keywords: media channel, politic, Ade Yasin Team.

${ }^{1}$ Dosen Tetap Program Studi Komunikasi, Sekolah Vokasi, IPB; hudi_santoso@yahoo.co.id Jurnal MetaKom Vol. 2 No. 1 Maret 2018|37 


\section{PENDAHULUAN}

\section{A. Latar Belakang}

Earl \& Garrett (2016) dalam jurnal studi gerakan social menjelaskan kondisi lingkungan informasi yang dihadapi oleh gerakan social, hasil penelitiannya menunjukkan peningkatan, hal tersebut memberikan persepsi secara tradisional tentang media, pesan, dan komunikasi yang digunakan dalam studi gerakan sosial kurang relevan. Selain itu Cristina dan Kevin (2017) mengungkapkan bahwa diperlukan pengembangan gagasan tentang teknologi media movement sebagai saluran penggunaan teknologi informasi dan komunikasi (TIK) secara social dan gerakan politik. Perkembangan teknologi yang memungkinkan integrasi yang lebih baik, berbeda dengan tradisi intelektual yang saat ini fokus pada seperangkat empiris yang sama fenomenanya. Cristina dan Kevin (2017) juga menyoroti cara yang digunakan untuk menekan gerakan social dan mobilisasi akar rumput. Dengan memetakan posisi dalam mengidentifikasi dan memberikan arahan kepada tiga area penelitian yang luas yang menuntut pertimbangan lebih lanjut: (i) pertanyaan tentang kekuasaan dan agensi gerakan sosial di Indonesia; (ii) hubungan antara, di satu sisi, gerakan social, teknologi dan media sebagai politik (yaitu cyberpolitik dan technopolitics), dan di sisi lain, penggunaan digital kuantum dan di mana-mana alat di era digital; dan (iii) pentingnya pembagian digital yang terpotong dan di luar gerakan social.

Alice Mattoni (2017) membahas dua aspek utama yang berkaitan dengan interaksi antara gerakan sosial dan teknologi digital. Pertama, ini mencerminkan kebutuhan yang mencakup dan menggabungkan pendekatan teoritis yang berbeda dalam gerakan social sehingga bisa membangun pemahaman yang lebih bermakna tentang bagaimana pelaku gerakan social berurusan dengan teknologi digital dan dengan hasil apa di masyarakat. Secara khusus, artikel tersebut berpendapat bahwa media ekologi dan media mainstream. Matoni juga menggunakan perspektif praktik media untuk mengeksplorasi dua trend yang saling terkait dalam masyarakat kontemporer bahwa personalisasi dan individualisasi politik, dan peran akar rumput dalam mobilisasi pilihan politik. 
Hal yang berbeda diungkapkan Nurhajati dan Moenawar (2014) menurutnya Strategi Pemasaran politik pastilah diperlukan sebagai bagian dari komunikasi politik. Dari hasil penelitiannya didapatkan beberapa partai sudah sangat serius menjalankan strategi pemasaran politiknya melalui media online. Sementara beberapa partai lainnya tampak tidak terlalu serius menjalankan strategi pemasaran politiknya, menganggap media online bukan sesuatu yang perlu mendapatkan perhatian.

Media sebagai saluran komunikasi politik mempunyai peranan dan tujuan yang sangat penting sebagai publisitas politik terhadap masyarakat luas. Seiring perkembangan teknologi dan informasi baik media cetak maupun elektronik untuk mempercepat arus informasi kepada khalayak sangat efektif. Selain itu pemanfaatan media oleh komunikator politik juga memberikan andil dalam mempopulerkan nama calon serta pasangan calon. Segala kegiatan yang ada nuansa politik diangkat media bertujuan sebagai sarana publisitas namun juga berperan dalam mempengaruhi khalayak.

Pemilihan kepala daerah (pilkada) langsung merupakan momentum politik dan bagian dari sejarah demokrasi Indonesia. Keputusan penyelenggaraan pilkada langsung tidak dapat dilepaskan dari serangkaian keputusan politik penting di era reformasi. Dalam Pemilihan Bupati (Pilbup) Bogor 2018 Partai Persatuan Pembangunan mendeklarasikan Ade Munawaroh Yasin sebagai Calon Bupati Bogor 2018. Ade Munawaroh Yasin adalah adik dari mantan Bupati Bogor Rahmat Yasin. Partai Persatuan Pembangunan juga meyakini Ade Yasin akan menang mutlak di Pilbup Bogor 2018 dan tim pemenangan adik dari Rachmat Yasin ini menargetkan 1,5 juta suara untuk Ade Yasin.

\section{B. Tujuan}

Tujuan dari penulisan makalah ini untuk menganalisis saluran media politik dinasti Yasin dalam Pilkada Kabupaten Bogor. 


\section{METODE}

Metode yang digunakan dalam penulisan makalah ini menggunakan studi literatur (literature study) dan studi kasus (case study) terkait dengan saluran media komunikasi yang digunakan tim sukses Ade yasin dalam pilkada Kabupaten Bogor. sumber data sekunder yang diperoleh melalui hasil survey/ penelitian. Lembaga riset Indobarometer terkait dengan survey calon Bupati/ Wakil Bupati, Gubernur/ wakil Gubernur di Jawa Barat tahun 2017. Selanjutnya dianalisis dalam perspektif komunikasi politik dan pembangunan.

\section{HASIL ANALISIS DAN PEMBAHASAN}

\section{A. Saluran Media Politik Dinasti Yasin}

Saluran media massa adalah segala bentuk media massa yang dapat digunakan oleh pihak-pihak yang berkomunikasi untuk menyampaikan pesan-pesan mereka. Media massa biasanya lebih efektif dan lebih murah untuk mengenalkan inovasi tahap-tahap penyadaran dan menumbuhkan minat, karena lebih menarik, serta dapat menjangkau penerima manfaat yang sangat luas, termasuk daerah-daerah terpencil yang susah dijangkau (Mardikanto 2010).

Dalam praktek komunikasi pembangunan, terutama fasilitator harus mampu mengidentifikasi dan sekaligus memilih saluran/media yang efektif. Pengertian efektif ini, di satu pihak disukai penerima manfaatnya, dan di lain pihak dia harus mampu dan trampil menggunakan atau mengoperasionalkan. Tentang hal ini, jika inovasi dapat dengan mudah dan jelas dapat tersampaikan lewat media massa, atau sebaliknya jika kelompok menerima manfaatnya dapat dengan mudah menerima inovasi yang tersampaikan melalui media masa, maka proses adopsi akan berlangsung relative lebih cepat disbanding dengan inovasi yang harus tersampaikan lewat media antar pribadi (Mardikanto 2010).

Terkait dengan pemilihan saluran/media perlu dipahami beragam karakteristik masing-masing saluran/media, seperti dalam Tabel 1. 
Tabel 1. Karakteristik Saluran Komunikasi

\begin{tabular}{|l|l|l|l|}
\hline No & Karakteristik & Saluran AntarPribadi & $\begin{array}{l}\text { Saluran } \\
\text { Media Masa }\end{array}$ \\
\hline 1 & Arus Pesan & Cenderung arah arah & $\begin{array}{l}\text { Cenderung Searah } \\
\text { melalui media }\end{array}$ \\
\hline 2 & Konteks komunikasi & Tatap Muka & Rendah \\
\hline 3 & Tingkat umpan balik yang terjadi & Cepat & Relatif rendah \\
\hline 4 & $\begin{array}{l}\text { Kemampuan mengatasi tingkat } \\
\text { Selektivitas Tinggi }\end{array}$ & Recepatan jangkauan terhadap & Relatif lambat \\
\hline 5 & Kecepatance yang besar & Penambahan & Perubahan sikap \\
\hline 6 & Efek yang mungkin terjadi & \\
\hline
\end{tabular}

Sumber: Mardikanto (2010)

Menurut Mardikanto (2010) pilihan terhadap penggunaan saluran komunikasi banyak bergantung pada maksud dan tujuan komunikasi. Media masa akan berperan secara efektif dalam merubah pendapat, sedangkan komunikasi antar pribadi umumnya lebih efektif dalam merubah sikap. Pesan-pesan melalui media masa memang kurang kuat dalam merubah sikap, kecuali kalau pesan-pesan tersebut justru memperkuat nilai-nilai dan kepercayaan (belief) penerimanya, sedangkan pesan-pesan yang bertentangan akan disaring melalui tingkat selektivitas mereka.

Mekanisme selektivitas senantiasa terjadi baik pada komunikasi antar pribadi maupun pada komunikasi massa, hanya pada komunikasi masa tampaknya mekanisme ini lebih berperan. Saluran komunikasi yag tepat akan dipilih berdasarkan tujuan dari sumber komunikasi serta pesan yang akan disampaikan pada audience. Seringkali melalui pemanfaatan berbagai jenis media massa dan penggabungannya dengan saluran komunikasi antara audience dalam jumlah besar dan mengharapkan suatu perubahan yang meluas.

Saluran komunikasi adalah alat serta sarana yang memudahkan penyampaian pesan. Pesan disini bisa dalam bentuk lambang-lambang pembicaraan seperti 
kata, gambar, maupun tindakan. Atau bisa pula dengan melakukan kombinasi lambang hingga menghasilkan cerita, foto (still picture atau motion picture), juga pementasan drama. Alat yang dimaksud disini tidak hanya berbicara sebatas pada media mekanis, teknik, dan sarana untuk saling bertukar lambang, namun manusia pun sesungguhnya bisa dijadikan sebagai saluran komunikasi. Jadi, lebih tepatnya saluran komunikasi itu adalah pengertian bersama tentang siapa dapat berbicara kepada siapa, mengenai apa, dalam keadaan bagaimana, sejauh mana dapat dipercaya. Komunikator politik, siapapun ia dan apapun jabatannya, menjalani proses komunikasinya dengan mengalirkan pesan dari struktur formal dan non-formal menuju sasaran (komunikan) yang berada dalam berbagai lapisan masyarakat.

Politik seperti komunikasi adalah proses dan seperti komunikasi politik melibatkan pembicaraan. Ini bukan pembicaraan dalam arti sempit seperti kata yang diucapkan, melainkan pembicaraan yang lebih inklusif, yang berarti segala cara orang bertukar simbol, kata-kata yang dituliskan dan diucapkan, gambar, gerakan, sikap tubuh, perangai dan pakaian. Ilmuwan politik Mark Roelofs menyatakan dengan cara sederhana, "Politik adalah pembicaraan, atau lebih tepat kegiatan politik (berpolitik) adalah berbicara." ia menekankan bahwa politik tidak hanya pembicaraan, juga tidak semua pembicaraan adalah politik. Akan tetapi hakekat pengalaman politik dan bukan kondisi dasarnya, ialah bahwa kegiatan berkomunikasi antara orang-orang.

Beberapa bentuk saluran komunikasi politik yang akan diungkapkan disini, dalam fungsi yang berbeda memang telah dikemukakan sebelumnya yakni sebagai komunikator dalam komunikasi politik, oleh karena beberapa unsur tertentu yang dimaksudkan ternyata memang bisa berfungsi ganda. Ia dapat berfungsi sebagai sumber/komunikator di satu saat, tetapi pada waktu tertentu lebih berfungsi sebagai saluran atau media, dan pada waktu yang lain berfungsi sebagai keduanya.

Kegandaan fungsi itu bukanlah sesuatu yang aneh karena suatu pihak dalam berlangsungnya proses komunikasi memang tergantung dari mana kita akan 42 | Saluran Media Politik Dinasti Yasin Dalam Pilkada Kabupaten Bogor 
meninjaunya. Birokrasi (pemerintah) misalnya, di satu pihak merupakan komunikator yang menyampaikan pesan-pesan yang berasal dari pemerintah, namun dalam kesempatan lain ia juga dapat berfungsi sebagai saluran bagi lewatnya informasi yang berasal dari khalayak masyarakat. Fungsi yang ganda itu terutama ditemui pada unsur-unsur yang bersifat organisasional/institusional seperti pemerintah, partai politik, kelompok kepentingan, kelompok penekan, dan media massa.

Hj Ade Munawaroh Yasin (Ade Yasin), calon Bupati Bogor sudah melakukan sosialiasi kepada masyarakat Kabupaten Bogor sejak tahun 2016. Hanya saja pola saluran media komunikasinya belum terstruktur, sistematis dan massif. Saat itu saluran media komunikasinya masih bersifat langsung misalnya menghadiri acara keagamaan, sosial dan olahraga. Baru, di awal tahun 2017 polanya sudah mulai dibangun secara terstuktur dengan dibentuk tim pemenangan tingkat Kabupaten Bogor pada bulan Februari 2017. Setelah dibentuk Tim Pemenangan tingkat Kabupaten (TPK), tim bergerak dengan membentuk Tim Pemenangan tingat Kecamatan (TPC) di 40 Kecamatan se Kabupaten Bogor. TPC-TPC ini dilantik langsung oleh Ade Yasin. Konsolidasi TPC selesai pada bulan April 2017.

TPK adalah mesin politik yang dibentuk untuk mengakomodasi para pendukung dan relawan Ade Yasin yang berada di luar partai. Latar belakang Ade Yasin adalah Ketua DPW PPP Jabar dan tentu PPP sebagai mesin partai utama Ade Yasin. Namun, modal PPP saja tidak cukup. Karena Pilkada itu bicara sosok/figur. Magnet sosok lebih kuat dari mesin partai. Untuk itu dibutuhkan rumah bagi pendukung yang bukan orang partai tetapi mau memilih Ade Yasin. Maka hadirlah Tim Pemenangan, juga relawan dan Rachmat Yasin Center (RYC). RYC adalah kumpulan veteran-veteran Pilkada 2008 dan 2013 yang menjadi salah satu motor kemenangan Rachmat Yasin yang juga kakak dari Ade Yasin. Saat ini Ade Yasin memiliki empat mesin politik, yakni partai, tim pemenangan, RY Center dan relawan.

Pada bulan April, Indobarometer sebuah lembaga survey ternama nasional menggelar survey Pilkada Kabupaten Bogor. Harus diakui hasilnya, elektabilitas 
Ade Yasin berada di nomor tiga. Hal tersebut saluran media komunikasi menjadi salah satu akar permasalahan selain penyebab yang lain. Berangkat dari hasil survey tersebut beberapa perbaikan dilakukan. Pada awal sosialisasi kepada masyarakat, nama yang ditonjolkan adalah Ade Munawaroh Yasin atau disingkat AMY. Pasca survey, nama penyebutan diganti menjadi Ade yasin dan tidak boleh disingkat. Hal Ini dilakukan untuk mengasosiasikan bahwa Ade Yasin adalah adik atau saudara Rachmat Yasin yang dalam survey April 2017 mudah dikenal masyarakat Kabupaten Bogor. Penggantian nama Ade Yasin dilakukan dengan tujuan lebih popular dalam masyarakat dibandingkan nama AMY. Hal tersebut menarik dalam penggunaan nama dinasti Yasin dalam Pilkada Kab Bogor.

Dari hasil survey tersebut, ditemukan fakta tingkat sosialiasinya masih lemah. Maka, diproduksi alat peraga besar-besaran seperti baliho, spanduk, stiker dan diinstruksikan untuk dipasang di seluruh wilayah di Kabupaten Bogor. Dari arus bawah juga ada partisipasi dari relawan untuk memproduksi dan memasang alat peraga secara sukarela. Pasca survey, RYC menggelar rapat kerja dan menghidupkan kembali mesin politiknya.

Berangkat dari hasil survey dimana Ade Yasin lemah salam sosialisasi di dunia maya, tim pemenangan membentuk tim divisi IT dan membentuk pasukan CyberArmy. Pasukan khusus ini dibertugas untuk melawan berbagai kampanye hitam di dunia maya. Selain tugas utamanya mensosialisasikan setiap kegiatan Ade Yasin di dunia maya.

Pada bulan Juli tim pemenangan menggelar Rapat kerja dan menginstruksikan agar TPC mengkonsolidasikan timnya hingga tingkat desa. Jadi, struktur TPK dibentuk hingga tingkat Desa (TPDes) berjumlah lima orang. Konsolidasi juga dilakukan ke kepala-kepala desa. Mantan kepala desa juga diorganisir dalam organisasi "RELASI", salah satu relawan Ade Yasin. Kepala desa dan mantan kepala desa ini mendapat tugas mengorganisir RT dan RW yang kemudian dikumpulkan dalam bentuk silatarahmi akbar RT dan RW per daerah pemlihan. RT, RW, amil, Ketua BPD diberikan seragam batik. Pengorganisasiann dilakukan juga di kalangan ulama. Pengurus MUI tingkat Kabupaten Bogor, kecamatan 44 | Saluran Media Politik Dinasti Yasin Dalam Pilkada Kabupaten Bogor 
dikonsolidasikan. Mereka dibuatkan organisasi majelis zikir Ar Rahman. Tugasnya melaksanakan kegiatan-kegiatan dakwah di kecamatan atau daerah pemilihan.

Setelah enam bulan bekerja, pada November 2017 Indobarometer menggelar survey yang kedua. Hasilnya, tingkat elektabilitas Ade Yasin sudah berada di peringkat pertama. Artinya kerja-kerja mesin politik Ade Yasin sudah mulai kelihatan. Berangkat dari paparan di atas, maka peran opinion leader sebagai saluran komunikasi menempati posisi yang sangat penting. Ini didukung oleh hasi survey dimana tokoh-tokoh yang berpengaruh adalah kepala desa, ulama, Ketua RW, Ketua RT. Orang-orang inilah yang menjadi sandaran masyarakat yang akan menggunakan hak pilihnya. Mengkonsolidasikan opinion leader secara tepat dan terukur untuk menaikkan elektabilitas.

Dengan saluran media komunikasi yang fleksibel, maka komunikasi yang digunakan oleh tim sukses Ade Yasin bersifat terbuka pada birokrasi, kelompokkelompok kepentingan, dan partai politik, sampai tingkat tertentu dapat diatur dan dikendalikan dengan publisitas. Pada saat yang sama, kepentingankepentingan yang laten (tidak dinyatakan secara terang-terangan) di tengah masyarakat dapat dibuat menjadi eksplisit melalui media komunikasi yang lebih netral.

Pada sebagian masyarakat akar rumput tim relawan Ade Yasin memandang pentingnya pembangunan media massa modern sebagai suatu kekuatan untuk mempengaruhi khalayak, sekaligus sebagai daya energi untuk mengerakkan modernisasi saluran media diantaranya penggunaan kekuatan media sosial. Dengan tujuan menanggulangi masalah-masalah yang dihadapi dalam hal hoax, termasuk hoax yang dikonotasikan membangun, bahasa, perbedaan tingkat pengetahuan, kepercayaan, dan kebiasaan, maka perluasan komunikasi berfungsi sebagai jembatan bagi sistem-sistem yang tadinya dicirikan oleh arus komunikasi yang heterogen. 
Masalah membangun identitas, Tim Ade Yasin memandang sebagai persoalan yang kompleks. Disamping sebagai kekuatan positif media, pengembangan suatu kultur politik yang stabil dan homogen akan tergantung dalam banyak hal kepada arah yang dikembangkan oleh struktur komunikasi yang ikut serta dari kalangan partai, kelompok kepentingan, dan para pemimpin opini, yang berhubungan dengan warga masyarakat secara lebih langsung.

Sebagian informasi, khususnya yang disampaikan oleh media massa akan melintasi garis-garis batas geografis dan kelas sosial. Namun dua karakteristik perubahan attitude akan membatasi dampak media tersebut. Yang pertama adalah interpretasi informasi melalui media massa tentunya akan dilakukan oleh para tim Sukses Ade yasin Pemimpin opini itu sendiri akan sangat dipengaruhi oleh hubungan antar personanya (jaringan sosialnya), yang menurut penelitian selama ini menunjukkan hasil yang konsisten, bahwa pengaruhnya lebih kuat dalam hal persuasi dibandingkan media massa.

Yang kedua, sekalipun secara ilmiah masih diperdebatkan, tapi dalam banyak hal, media massa diakui sebagai saluran yang mempunyai kemampuan untuk menyampaikan lebih dari sekedar informasi politik. Artinya, media massa dapat dibuktikan mempunyai efek politik dalam suatu kelangsungan sistem politik suatu masyarakat. Kekuatan media, dalam kaitan ini, menurut Gurevitch dan Blumler (dalam Nasution, 1990) bersumber dalam tiga hal, yaitu struktural, psikologis, dan bersifat normatif.

Akar struktural kekuatan media massa bersumber pada kemampuannya yang unik untuk menyediakan khalayak bagi para politisi yang ukuran dan komposisinya tidak akan diperoleh para politisi dimaksud melalui alat yang lain. Sedangkan akar psikologis dari kekuatan media bersumber pada hubungan kepercayaan dan keyakinan yang berhasil diperoleh (meskipun dengan tingkat yang berbeda-beda) oleh organisasi media dari anggota khalayaknya masingmasing. Ikatan saling percaya ini tumbuh berdasarkan pada pemenuhan harapan khalayak selama ini dan validasi dari hubungan percaya mempercayai di masa lampau antara media yang bersangkutan dengan khalayaknya.

46 | Saluran Media Politik Dinasti Yasin Dalam Pilkada Kabupaten Bogor 
Kombinasi antara akar struktural dan akar psikologis tadi memungkinkan media mendudukan diri di tengah-tengah antara politisi dan khalayak dan sekaligus mencampuri proses politik yang berlangsung. Campur tangan tersebut mungkin saja tidak disukai oleh banyak pihak termasuk kalangan politik dimaksud. Di sini kemudian, tampillah sifat normatif media yang bersumber pada prinsip-prinsip demokrasi mengenai kebebasan menyatakan pendapat, kebutuhan akan perlindungan terhadap warga negara dari penyalahgunaan kekuatan politik, yang memberi legitimasi kepada peran independensi media dari kendali politik (handout komunikasi massa: teori-teori normatif komunikasi massa).

Media massa dianggap memiliki peranan yang unik dalam pembangunan politik, karena memiliki suatu instrumen teknologi yang independen, yang produknya dapat menjangkau ke tengah-tengah masyarakat dalam jumlah yang besar (Gerbner dalam McQail, 1987). Di samping itu, media massa menganggap diri sebagai perantara yang independen antara pemerintah dengan publik.

Media dalam sebuah komunikasi politik mempunyai peranan yang sangat penting karena sebagai publisitas politik terhadap masyarakat luas. Tentunya dengan tujuan khalayak mengetahui agenda politik setelah itu simpati dan menjatuhkan pilihannya kepada partai tersebut. Siapapun komunikator atau aktivis politik akan berusaha untuk menguasai media. Tidak heran, barang siapa yang telah menguasai media, maka dia hampir memenangi pertarungan politik. Semenjak kemajuan teknologi dan informasi yang revolusioner, media cetak maupun elektronik mengantarkan informasi kepada khalayak sangat efektif. Pemanfaatan media untuk mendongkrak popularitas sebenarnya telah mulai marak dan bebas sejak Pemilu 1999 dan semakin menguat di Pemilu 2004 hingga Pemilu 2009. Segala kegiatan yang ada nuansa politik diangkat media bertujuan tidak hanya sebagai sarana publisitas namun juga mempengaruhi khalayak untuk memilihnya.

Media massa oleh pihak media sering disebut sebagai the fouth estate dalam kehidupan sosial ekonomi. Hal ini terutama disebabkan oleh peran suatu persepsi tentang peran yang dapat dimainkan oleh media massa dalam kaitannya 
dengan pengembangan kehidupan sosial ekonomi dan politik masyarakat. Sebagai suatu alat untuk menyampaikan berita, penilaian atau gambaran umum tentang banyak hal, ia mempunyai kemampuan untuk berperan sebagai institusi yang dapat membentuk opini publik. Antara lain, media massa juga dapat berkembang menjadi kelompok penekan atas suatu ide atau gagasan, dan bahkan suatu kepentingan atau citra yang ia representasikan untuk diletakkan dalam kontek kehidupan yang lebih empiris.

Hadirnya media massa sebagai sarana untuk menyampaikan pesan-pesan terutama mengenai politik akan mempermudah setiap komunikator politik dalam menyampaikan dan memperkenalkan siapa dirinya kepada khalayak. Begitu berkuasanya media dalam mempengaruhi pikiran, peranan, dan perilaku masyarakat, sehingga Kevin Philips dalam buku responsibility in mass Communication mengatakan, bahwa era sekarang lebih merupakan mediacracy, yakni peemerintahan media, daripada demokrasi pemerintahan rakyat.

Kekuatan media massa (powerful media) sebagai saluran untuk mempengaruhi khalayak, telah banyak memberikan andil dalam pembentukan opini publik. Kemampuan melipatgandakan pesan-pesan politik di media massa mempunyai dampak terhadap berubahnya perilaku pemilih. Maka dari itu, bagi para elit politik yang ingin bertarung memperebutkan kursi kekuasaan, akan berusaha memanfaatkan media massa untuk tujuan publikasi dan pembentukan citra. Media dalam bentuk apapun adalah saluran komunikasi seorang kandidat kepada khalayak yang dikatakan efektif dan efisien pada masa kampanye modern saat ini. Ada beberapa media yang sangat penting dalam mempublikasikan agenda politik:

1. Media telepon; merupakan alat komunikasi lisan satu-kepada-satu yang memiliki beberapa kegunaan bagi kampanye kontemporer. Media ini kerap digunakan oleh Tim Sukses dan relawan Ade Yasin untuk komunikasi secara pribadi serta dalam konteks organisasi. Media telepon sering digunakan dalam mengumpulkan dana, mengarahkan pemilih untuk datang ke tempat kampanye. Atau terkadang media telepon juga biasa digunakan untuk 48 | Saluran Media Politik Dinasti Yasin Dalam Pilkada Kabupaten Bogor 
memperkenalkan kandidat melalui rekaman suara yang dapat diputarkembali. Telepon pun saat ini masih digunakan sebagai media survey tim Ade Yasin tentang opini para calon pemilih; polling telepon.

2. Media radio, Menurut McLuhan, terdapat resonansi antara radio dan telinga serta pikiran manusia, resonansi yang menyajikan peluang besar bagi kampanye radio. Di samping itu, radio juga merupakan saluran massa bagi kaum minoritas walaupun dalam perkembangannya kaum mayoritas pun masih belum bisa meninggalkannya. Meskipun radio tidak menampilkan visual/gambar hidup, namun media satu ini bisa merambah ke lokasi di mana media lain susah bahkan tak bisa menjangkaunya.Tim Sukses Ade Yasin juga menggunakan media radio di wilayah kota/Kabupaten Bogor dalam mengenalkan serta mensosialisasikan program-program yang akan dikampanyekan.

3. Media Televisi, Di Amerika, penggunaan televisi sebagai media kampanye sudah sejak dasawarsa 1950-an dan 1960-an dimulai. Penekanan dalam kampanyenya pun beragam, mulai dari pembuatan citra; di mana penggunaan media ini untuk memproyeksikan atribut-atribut terpilih dari kandidat. Hingga penekanan berkembang pada tahun 1970-an menjadi pengaturan dan pembahasan pokok masalah kampanye. Teknik untuk membangun citra sang kandidat pun beragam dari melalui publisitas gratis hingga pada beriklan di televisi yang mesti bayar. Sebenarnya sudah ada pengaturan tentang tata cara beriklan di media massa, terutama di televisi. Peliputan berita pasangan kandidat Ade Yasin di media televisi tentu mendapat durasi yang relatif lebih panjang dibandngkan sebelum masa pilkada saat ini. Hal ini dikarenakan Tim sukses sudah merancang strategi penggunaan media sebagai saluran komunikasi politik.

4. Media Cetak, Meskipun media elektronik ditambah dengan media inovasi sudah semakin maju, tetap saja media cetak belum akan ditinggalkan khalayak massa. Terdapat dua tipe media cetak yang kerap dijadikan sebagai media kampanye, oleh tim sukses Ade Yasin yakni melalui surat kabar dan majalah dalam hal ini media cetak di Bogor yang jangkauannya diharapkan bisa menginformasikan ke masyarakat hingga ke pelosok desa. 
Surat Kabar. Tiga tipe isi surat kabar yang bertindak sebagai sarana bagi komunikasi kampanye, yakni isi berita, editorial, dan iklan. Semuanya membantu pembinaan citra dan penyajian masalah. Namun, pembuatan citra adalah yang paling utama. Setelah dilakukan penelitian terhadap ketiga tipe isi surat kabar dalam hal kampanye politik, maka didapatkan sebuah kesimpulan bahwa materi yang disajikan lebih kepada citra sang kandidat ketimbang masalah yang dihadapi. Dalam berbagai pilkada, media surat kabar menjadi ruang publisitas politik di antara partai-partai peserta pilkada, mengingat salah satu media yang cukup representatif untuk mensosialisaikan agenda-agenda partainya masingmasing.

Di tengah-tengah segitiga persaingan memperebutkan uang pengiklan dan perhatian publik, media telah mengembangkan dalam berbagai peran. Sebagai media informasi, radio dan televisi unggul dalam penyampaian berita yang dilengkapi dengan ulasan penjelas. Kalau media siaran memberi perhatian pada suatu peristiwa lain berkurang. Celah inilah yang kemudian diisi dengan koran. Seringkali koran memberikan banyak hal sehingga kedalamannya pun terbatas. Celah ini lalu diisi oleh majalah.

Majalah sebagai saluran media politik seringkali meliput suatu yang diberikan oleh media siaran secara lebih panjang dan lebar. Seseorang yang tertarik untuk mengetahui yang lebih banyak tentang suatu yang diberitakan di televisi akan mencarinya di majalah. Jika ia akan lebih mendalaminya, ia akan mencari buku atau film dokumenter. Hal ini juga menandakan bahwa peran media sebagai saluran media informasi serta pentingnya sebagai penyampai informasi. Maka dari itu berbagai media di atas mempunyai peran yang saling melengkapi dan itu sangat efektif dalam menyampaikan pesan-pesan politik.

Strategi komunikasi pembangunan yang digunakan oleh Ade Yasin untuk memperoleh dukungan rakyat Bogor adalah dengan membuat Program-program andalan salah satunya untuk memperkuat pembangunan perekonomian di kabupaten Bogor. dengan cara mengoptimalisasikan peran BUMDes di 417 desa di Kabupaten Bogor. Dengan program tersebut diharapkan dapat membuat 50 | Saluran Media Politik Dinasti Yasin Dalam Pilkada Kabupaten Bogor 
warga kabupaten Bogor bisa hidup lebih sejahtera. Hal ini bertujuan untuk mengurangi mobilisasi warga bogor mencari kerja ke Jakarta. Dengan luas 2.664 kilometer persegi dan jumlah penduduk 5,5 juta lebih, serta sumber daya alam yang melimpah, rasanya mustahil jika Kabupaten Bogor tidak bisa maju melebihi daerah lain. Menguatkan perekonomian berbasis pedesaan, yakni dengan memeratakan pembentukan Badan Usaha Milik Desa atau biasa disebut BUMDes. Dalam peraturan yang ada secara jelas dikatakan BUMDes dapat didirikan dalam bentuk Usaha Bersama (UB). Jadi badan hukumnya adalah usaha bersama. Undang-undang melarang mendirikan BUMDes dengan badan hukum Koperasi, Perseroan Terbatas (PT), Badan Usaha Milik Daerah (BUMD), Commmanditaire Vennootschaap (CV), Usaha Dagang (UD) dan sejenisnya. Dalam BUMDes, manajer dan karyawannya dipilih dari masyarakat desa. Sementara kepala desa bertindak sebagai komisaris atau pengawasnya. Sementara modalnya, menurut ketentuan yang ada, bisa dari pemerintahan desa, kekayaan desa yang dipisahkan, tabungan masyarakat, bantuan pemerintah pusat, bantuan pemerintah provinsi dan bantuan pemerintah daerah. Atau bisa juga pinjaman dari lembaga keuangan atau kerja sama usaha dengan pihak lain," terangnya. Tim Ade Yasin menjelaskan banyak bisnis di pedesaan yang bisa digarap BUMDes ini. Di antaranya: usaha jasa, bisnis penyaluran sembilan bahan pokok (sembako), usaha perdagangan, usaha industri kecil, bisnis rumahan dan lain sebagainya.

Oleh karena itu, dalam perspektif pembangunan politik, Pemerintah Kabupaten Bogor perlu turun tangan dan memfasilitasi pembentukan semua BUMDes untuk kemajuan desa. Banyak hal yang bisa dilakukan pemerintah. Selain memberikan bantuan dana, pemerintah daerah juga bisa bekerja sama dengan kepala desa melakukan pembinaan manajerial kepada calon manajer BUMdes. Merumuskan proposal bisnis yang baik. Memberikan informasi pasar. Dan ini menjadikannya salah satu program andalan Tim Ade Yasin dalam menstrategi komunikasi politiknya untuk memenangkan Pilbup Bogor. 


\section{SIMPULAN}

Simpulan dari penulisan makalah ini tim sukses Ade Yasin memandang pentingnya pembangunan saluran media massa modern sebagai suatu kekuatan politik untuk mempengaruhi khalayak, sekaligus sebagai daya energi untuk mengerakkan modernisasi saluran media dengan penggunaan kekuatan media sosial. Dengan saluran media komunikasi yang fleksibel, maka komunikasi yang digunakan oleh tim sukses Ade Yasin bersifat terbuka pada birokrasi, kelompokkelompok kepentingan, dan partai politik, sampai tingkat tertentu dapat diatur dan dikendalikan dengan tujuan publisitas kepada masyarakat.

\section{DAFTAR PUSTAKA}

Arifin, Anwar. 2006. Pencitraan Dalam Politik, Strategi Pemenangan Pemilu Dalam Perspektif Komunikasi Politik. Jakarta: Pustaka Indonesia.

Ardianto, Elvinaro. 2007. Komunikasi Massa. Suatu Pengantar. Bandung, Simbosa Rekatama Media.

Earl Jennifer and Garett K. 2016. The new information frontier: toward amore nuaced view of social movement. University of new England.

Fominaya Cristina and Gillan K. 2017. Navigating the technology media movements complex. Cornell university library.

McQuail. 1987. Teori Komunikasi Massa ed. 2. Jakarta: Erlangga.

Mardikanto, Totok. 2010. Komunikasi Pembangunan. Surakarta: UNS Press.

Matoni Alice. 2017. A situated understanding of digital technologies in social movements. Media ecology and media practice approaches. The UC San Diego Library.

Nurhajati Lestari dan Moenawar G. 2014. Prosiding: Startegi Pemasaran politik pada ke 15 Partai peserta Pemilu 2014 (analisa strategi PR melalui media online). Jakarta. Fakultas Ilmu Komunikasi, Universitas Mercu buana Jakarta. 